\title{
Application of Scramble Learning Model to Improve Learning Outcomesof Chemistry Study High School Students 3 South Tambun
}

\author{
Vironi Trio Lasminar ${ }^{1}$, Nova Irawati Simatupang ${ }^{2}$, Familia Novita \\ Simanjuntak ${ }^{3}$
}

${ }^{1,2,3}$ Department of Chemistry Education, Universitas Kristen Indonesia, Jakarta, Indonesia

Email:vironi.tio@gmail.com ${ }^{1}$, simatupang_nova@ymail.com ${ }^{2}$,familia.novita@gmail.com ${ }^{3}$

\begin{abstract}
Chemistry learning at SMAN 3 Tambun Selatan is still dominated by teacher-centered information delivery, sample modeling and practice questions. As a result, students are less interested and more passive in the process of learning chemistry. Based on the results of the chemistry learning process questionnaire that has been filled out by students of class X and XI of SMAN 3 Tambun Selatan FY 2018/2019 the results obtained in the statement are able to understand the chemistry obtained answer "yes" as much as $42.5 \%$, do not feel difficulties in learning chemistry obtained "yes" answers as much as $6.3 \%$, and able to do chemical tasks without cheating obtained "yes" answers as much as $16.8 \%$. So, it can be said that the chemistry learning outcomes of SMAN 3 Tambun Selatan is very lacking. This study aims to determine the increase in chemistry learning outcomes of students at SMAN 3 Tambun Selatan TA 2018/2019. This study uses a pretest-posttest control group design. The study population was students of class X IPA SMAN 3 Tambun Selatan TA 2019/2020. The research sample consisted of two classes, namely class X IPA 4 as an experimental class using a scramble model and X IPA 5 as a control class without using a scramble model with a sample of 62 students. Normality and homogeneity tests use the Kolmogorov-Smirnov test and the Levene test. Hypothesis testing uses Paired sample ttest on the hypothesis of learning outcomes. There is an increase in chemistry learning outcomes. In the hypothesis test Ha learning outcomes are accepted, with the value of $t$ arithmetic $(29,133)>t$ table $(2,000)$.
\end{abstract}

\section{Keywords: Chemistry learning outcomes, Scramble learning model}

\section{INTRODUCTION}

Education plays an important role for the development of a nation. With education, a nation can achieve progress in all fields. Learning activities in Indonesia emphasize the transfer of knowledge and training (Murjani and Hamid, 2016). However, the way of learning chemistry has not changed much. In general, learning chemistry in high school is still dominated by the delivery of information that is centered on the teacher, giving examples and practice questions (Subagia, 2014). The goal of chemistry learning is that students are expected to be able to achieve better learning outcomes and students have more active roles in the learning process (Purba, 2017).

Chemistry lessons contain concepts and calculations related to daily life (Arafah and Hamid, 2016). The atomic structure is one of the class $\mathrm{X}$ chemicals taught at the beginning of the meeting. The importance of mastering this atomic structure material because it is the basis for students to study chemistry. The material is a gateway for students' understanding of further chemical materials. However, in the learning process teachers still tend to use teacher-centered learning methods (Arfiyah, et al, 2016). As a result, many students are less interested and feel bored with chemistry so that they are more passive in the learning process. There are still many problems in learning chemistry, such as difficulties in understanding chemical concepts, difficulties in chemical calculations, as well as difficulties in connecting concepts with daily life that can cause low learning outcomes in chemistry (Jauhariningsih, 2017).

Student learning outcomes are influenced by two factors, namely internal factors and external factors. Internal factors include fatigue, physical, and psychological factors, while external factors include family, community and school factors. Student learning outcomes show the ability and quality of students as an impact of the learning process that has been passed (Nurhasanah and Sobandi, 2016: 129). The interaction between educators and planned students both inside and 
outside the room to improve students' abilities is determined by learning outcomes (Afandi, Chamalah and Wardani, 2013). The learning outcomes according to Afandi, et al (2013) classified into three realms, namely cognitive, effective, and psychomotor. The cognitive domain includes learning outcomes related to memory, knowledge, and intellectual abilities. The learning process is considered successful if the absorption of the teaching material being taught reaches high achievements, both individually and in groups (Zaenab, 2018). Student learning assessments conducted by teachers are guided by competencies and indicators of competency achievement. There are three forms of assessment techniques for learning chemistry, namely test techniques, non-test

It is necessary to develop innovative and creative learning that can foster enthusiasm and strengthen students' memory of the material to be learned (Zaenab, 2018). This is consistent with the results of previous research which states that there is an increase in student chemistry learning outcomes taught by applying power point media on NHT type cooperative learning (Simatupang, 2016). The scramble learning model has several advantages that appear directly in the learning process, namely making it easier for students to find answers, encouraging students to learn to work on the problem, making lessons more interesting, making students challenged to work on existing problems in the game, and make students more active (Sitompul, 2018).

\section{METHOD}

\subsection{Research Design}

The study was conducted at SMA Negeri 3 Tambun Selatan class X IPA in the academic year 2019/2020. This research is a quasi-experimental study using a Pretest-posttest control group design research design. In this design there are 2 groups chosen randomly. The effect of the treatment is $(\mathrm{O} 2-\mathrm{O} 1)$ - (O4O3). The classes used in this study are the experimental class and the control class. The experimental class was treated with a scramble model while the control class used a teacher-centered learning method. The research design can be described as figure 1 (Sugiyono, 2017).

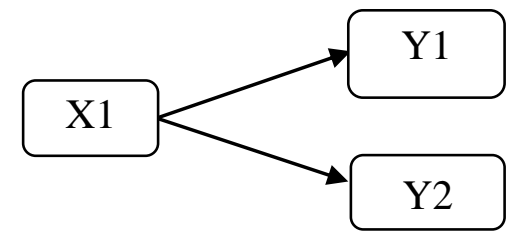

Figure $1:$ Research design
Information:

$\mathrm{X} 1=$ Scramble learning model

Y1 = Interest in learning chemistry

Y2 = Chemistry learning outcomes

\subsection{Population and Sampling Techniques}

The population in this study were all students of class X IPA of SMA Negeri 3 Tambun Selatan in the $2019 / 2020$ school year as many as 214 students consisting of X IPA 1 to X IPA 6. Determination of the study sample was done by simple random sampling. Class to be used in this study as many as 2 classes namely class X IPA 4 and X IPA 5.

\subsection{Data Collection Technique}

Data collection techniques used in this study were interviews (unstructured interviews) and tests.

\subsection{Research Instruments}

The test instrument used in this study was in the form of multiple choice with $\mathrm{C} 1-\mathrm{C} 3$ cognitive domains. The test instrument uses difficulty levels with easy, medium and difficult questions. Validation Techniques The test instrument uses the content validity and the construct validity. Reliability test for the items used Cronbach alpha technique. Analysis of construct validity and item reliability using the SPSS 16.0 For Windows application. Calculate the level of difficulty of the questions and the different power of problems by using the Microsoft Office Excel 2007 application.

\section{$2.5 \quad$ Test Requirements Analysis}

The normality test in this study used the Kolmogorov-Smirnov test with the help of SPSS 22 for Windows. Data is said to be normally distributed if the significance value of the output window of test of normality $>\alpha=0.05$. For homogeneity test used Levene-Test with the help of SPSS 22.0 for windows. Homogeneity test results of the variant are said to be homogeneous if Fhit $<$ Ftab $(\mathrm{F} \alpha(\mathrm{dk} 1, \mathrm{dk} 2))$, with $\alpha=$ $1 \%$ or sig value $>0.05$.

\subsection{Data Analysis Technique}

The main data used to see an increase in chemistry learning outcomes is the pretest and posttest results data. If the requirements are met that the sample comes from a normal and homogeneous population then data analysis will be performed. Analysis of improvement in 
learning outcomes using paired t-test with the help of SPSS 22.0 for windows.

$$
\begin{aligned}
& \mathrm{H}_{\mathrm{a}}: \mu_{1} \geq \mu_{2} \\
& \mathrm{H}_{\mathrm{o}}: \mu_{1}<\mu_{2}
\end{aligned}
$$

In this party test applies the provision that, if the price of $t$ arithmetic is smaller $(\leq)$ or equal to the price of $\mathrm{t}$ table, then $\mathrm{Ho}$ is accepted and $\mathrm{Ha}$ is rejected (Sugiyono, 2017). Data on chemistry learning outcomes can be presented in the form of frequency distribution tables and histograms.

\section{RESULT}

Before being given treatment in the control class and the experiment is pretested to know the initial conditions of students.

\subsection{Description of Pre-test Post-test Data Learning Outcomes of Chemistry Experiment Classes}

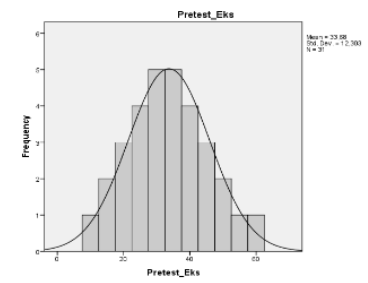

Figure 1. Histogram description of pretest data on the learning outcomes of experimental class chemistry.

Based on the pretest data of chemistry learning outcomes in the experimental class, there were 31 students in each class. Obtained mean data at pretest of 33.68 and at posttest of 90.61 with the difference in the mean score of the pretest-posttest data of 56.93. If seen from the pretest, the median score is 35.00 while the posttest is 87.00. The pretest standard deviation score in the experimental class was 12.303 and the posttest was 6.731. The minimum pretest score in the experimental class is 10 while the posttest is 80 .

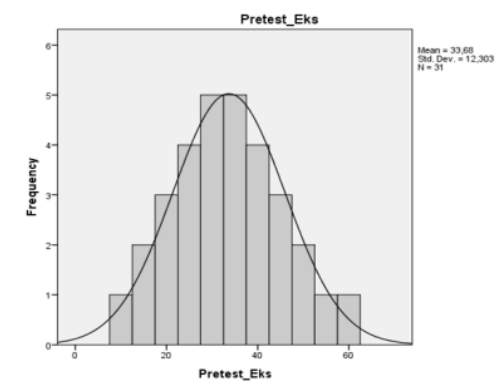

Figure 2. Histogram description of posttest data on learning outcomes of experimental class chemistry

\subsection{Description of Pre-test Post-test Data on Learning Outcomes of Control Class Chemistry}

The data obtained before and after the research is the pretest-posttest data which is used to ascertain whether there is an increase in the chemistry learning outcomes of students of Class X Science 4 and X Science 5 of SMAN 3 Tambun Selatan in Academic Year 2019/2020

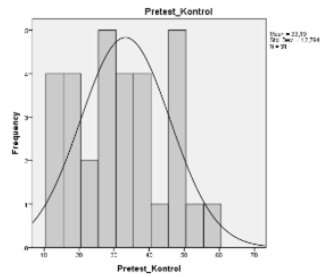

Figure 3. Histogram description of pretest data on the results of chemistry learning control class.

Based on the pretest data the learning outcomes in the control class have a total of 31 students each class. Obtained mean data at pretest of 33.19 and at posttest of 83.35 with the mean score difference from the pretestposttest data of 50.16. If seen from the pretest, the median score is 35.00 while the posttest is 87.00 . The pretest standard deviation score in the control class was 12.794 while the posttest score was 6.897. The minimum pretest score in the control class is 13 and the posttest is 67 .

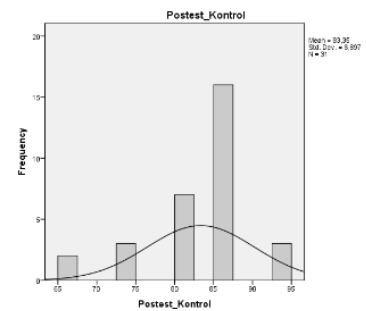

Figure 4. Histogram description of posttest data on the results of chemistry learning control class.

\subsection{Analysis of Research Instruments}

The type of test validity test consists of 2 test instruments namely content validity test and construct validity test. The content validity was carried out with the assistance of the Teaching and Education Faculty 
lecturers namely Ms. Elferida Sormin, S.Si, M.Pd and Mr. Nelius Harefa, S.Si, M.Pd as expert validators. The item test instrument prepared by the researcher was 47 items with 40 valid items and 7 invalid items. As for the test of the construct validity of the test instrument the questions were tested on students of class X IPA 2 of SMAN 3 Tambun Selatan in Academic Year 2018/2019 as many as 32 people. The test questions that will be submitted to students of class $X$ Science 2 in the 2018/2019 school year of SMAN 3 Tambun Selatan contain 39 test items. The significance level is $5 \%$ with $\mathrm{N}=32(\mathrm{df}=32-2=30, \alpha=0.05)$. Then obtained rtable $=0.291$. If $\mathrm{r}$ arithmetic $>\mathrm{r}$ table then the item can be said to be valid. The validity test results of the test instrument were calculated with the help of Microsoft Office Excel 2007.

Overall the items can be declared valid as many as 31 items by having the value of $r$ count $>r$ table. So based on the results of calculations there are 31 statements can be used in this study. However, researchers used 15 statements that were used as a test item to measure student chemistry learning outcomes.

\subsection{Reliability Test}

Chemistry learning reliability test results from the Cronbach's Alpha value of 0.833 which shows that the value of $\mathrm{r} 11$ obtained $>0.05$. So it can be concluded that the measuring instrument that researchers used in the study of chemistry learning outcomes was reliable because the Cronbach's alpha value> 0.05. Based on the validity and reliability tests above, there are 31 items that can be used to retrieve data on the chemistry learning outcomes of students in class X IPA 4 and X IPA 5 SMAN 3 Tambun Selatan.

\subsection{Level of Problem Difficulties}

Based on the calculation of the level of difficulty, the questions are divided into three categories: easy, medium, and difficult. For categorical questions, it is easy to find numbers $12,16,22,23,35$. For categorical questions, they are number $3,4,5,6,7,9,11,13,14$, $15,19,21,24,25,26,27,28,30,31,32,33,34,36,37$. Meanwhile, for categorical questions, it is difficult to find numbers $38,39$.

\subsection{Different power}

Based on the results of the calculation of different power problems divided into three categories, namely good, enough, and bad. For good categorical questions, there are numbers $7,24,25,26,27,30,37,38,39$. For categorical questions, there are enough in numbers 3,4 ,
$5,9,11,15,21,22,23,28,33,34,36$. Meanwhile, for the bad category questions found in numbers $6,12,13$, $14,16,19,31,32,35$. Based on the calculation of the problem analysis, the questions that can be used as research instruments are $3,4,6,7,11,12,19,21,23$, $24,13,15,38,39$ and 26.

\subsection{Test Requirements Analysis}

Before giving treatment to the experimental class and the control class the researcher conducted a pretest. After the pretest data was obtained the researchers conducted a data normality test with the help of SPSS 22 using the kholmogorov-smirnov test. Based on SPSS 22 output for windows, the sig value is 0.200 . Data can be said to be normally distributed if the value of sig> 0.05. Thus, the data in the experimental and control class can be said to be normally distributed because the results of the sig data pretest learning outcomes>0.05.

Homogeneity test in this study uses the lavene test method based on the significance value. If the significance value or sig $>0.05$ and the value of Lavene statistics $\mathrm{F}$ arithmetic $<\mathrm{F}$ table, then it can be said that the variance of the data population is the same or homogeneous. The data used in this test are pretest values from the experimental and control classes. Based on the SPSS 22.0 output, a sig value of 0.186 is obtained. The data can be said to be homogeneous if the sig value $>0.05$. Thus, the data in the experimental and control classes can be said to be homogeneous because the results of the pretest data sig values are greater than 0.05. In addition, based on the results obtained, the calculated $F$ value $(0.625)<F$ table (3.17).

\subsection{Hypothesis test}

The main data used to see improved learning outcomes are the pretest and posttest results data. Analysis of improvement in learning outcomes using paired t-test with the help of SPSS 22.0 for windows. Based on the results of SPSS 22.0 output shows that there is an increase in chemistry learning outcomes. So, it can be said that in the hypothesis test the learning outcomes of $\mathrm{Ha}$ are accepted. This is indicated by the value of $\mathrm{t}$ arithmetic $(29,133)>\mathrm{t}$ table $(2,000)$.

Table 1. Learning Outcomes

\begin{tabular}{|c|c|c|}
\hline $\mathrm{T}_{\text {count }}$ & $\mathrm{t}_{\text {table }}$ & Conclusion \\
\hline 29,133 & 2,000 & Ha be accepted \\
\hline
\end{tabular}


Improved chemistry learning outcomes by applying the scramble learning model and without applying the scramble model can be seen by calculating the gain score. Here are the average gain scores in the control and experimental classes.

Table 2. Comparison of Average Control and Experiment Class Gain Scores

\begin{tabular}{cccc}
\hline Class & $\begin{array}{c}\text { Mean gain } \\
\text { score }\end{array}$ & $\begin{array}{c}\text { Gain score } \\
\text { criteria }\end{array}$ & Category \\
\hline Control & 0,7508 & $\mathrm{~g}>0,7$ & High \\
Experiment & 0,8585 & $\mathrm{~g}>0,7$ & High \\
\hline
\end{tabular}

Based on the table above, the results obtained from the control class and experimental gain tests are 0.7508 and 0.8585. Based on table 4.1 the gain score in the control class is $g(0.7508)>0.7$, with a high category. In the experimental class with a gain score $g(0.8585)>$ 0.7 , in the high category. Although, the gain in the control class and experiment both have a high category. However, the highest increase in chemistry learning outcomes occurred in the experimental class with an average gain score of 0.8585 .

\section{DISCUSSION}

The purpose of this study was to determine the increase in student chemistry learning outcomes using the scramble learning model. This study was applied to two classes with atomic structure material and the development of atomic theory with a research sample of 71 students. The first step taken by researchers is to conduct observations by conducting interviews with chemistry teachers at SMAN 3 Tambun Selatan and giving questionnaires to the process of chemistry learning at students of SMAN 3 Tambun Selatan class $\mathrm{X}$ and XI Science. Based on the results of interviews with chemistry teachers and the results of the chemistry learning process questionnaire that have been filled out by students of class X and XI that the current problem is the decline in student chemistry learning outcomes of SMAN 3 Tambun Selatan.

The study was conducted in class $\mathrm{X}$ due to the first introduction of chemistry subjects in class X. Marshell in Darmadi (2017) said that children have an interest in learning. According to Darmadi (2017), learning must be able to attract attention as an example of teaching in an interesting way using props, developing / compiling evaluation tools, and planning programs using appropriate learning models. Therefore, the researcher wants to apply the Scramble learning model which in its application uses the media in the form of randomized question cards and answer cards and students will rearrange them correctly in groups. Thus, by using this model the researcher hopes that the students' chemistry learning outcomes will increase after being treated.

The first thing that researchers do is validate the test instrument that will be used at the time of the study. In a multiple choice question test, before the question is validated the researcher makes 47 questions. After content validation and construct validation, 31 valid statements were obtained with a reliability of 0.833 . About 15 questions will be used during the research. The selection of questions to be used at the time of the study is based on indicators of achievement of competence, cognitive domain, level of difficulty, and different power. The cognitive domain used is $\mathrm{C} 1$ to $\mathrm{C} 3$ with a problem ratio of 1: 1: 1 . The cognitive domain is the first indicator $\mathrm{C} 1-\mathrm{C} 2$, the second and third indicators C1-C3.

After determining the research instrument, the researcher conducted a pretest to get the results of normality and homogeneity tests in the control and experimental classes. Based on the pretest data of the chemistry learning outcomes obtained, the normality and homogeneity test in the control and experimental classes is 0.200 and 0.186 . This shows that the control class and the experimental class are normal and homogeneous. Thus, researchers used the parametric test as a follow-up test to test the hypothesis. The hypothesis test used to test the improvement in learning outcomes is the paired sample t-test.

After being given a pretest and treatment, the next step is to provide a posttest to get data on the improvement of student chemistry learning outcomes on the material of atomic structure. The results of the pretest and posttest data were analyzed to see an increase in learning outcomes. Based on the pretest data of learning outcomes obtained, the mean in the control class is 33.19. While the mean posttest in the control class was 83.35. Difference in mean pretest-posttest data was 50.16. The minimum pretest score in the control class was 13 while in the posttest it was 67 . Based on the pretest data the learning outcomes obtained, the mean in the experimental class was 33.68. While the mean posttest in the experimental class was 90.61. Difference in mean pretest-posttest data was 56.93. The minimum score of pretest in the experimental class was 10 while in the posttest it was 80.

\section{CONCLUSIONS}

a. There is an increase in the chemistry learning outcomes of students at SMAN 3 Tambun Selatan 
by applying the scramble learning model obtained based on a hypothesis test using paired sample t-test with $t$ count $(29,133)>t$ table $(2,000)$. This means that $\mathrm{Ha} 2$ is accepted and $\mathrm{H} 02$ is rejected. Gain test results respectively in the control and experimental class obtained 0.7508 and 0.8585 .

b. Learning using scramble learning models that are applied to the atomic structure material and the development of the atomic model is proven to improve student chemistry and learning outcomes

\section{REFERENCES}

[1] Afandi, M., Chamalah, E., dan Wardani, O. P., 2013. Model dan Metode Pembelajaran di Sekolah. Semarang: UNISSULA Press

[2] Arafah, S., \& Hamid, A., 2016. Meningkatkan Motivasi Dan Hasil Belajar Siswa Pada Materi Sistem Koloid Dengan Menggunakan Model Pembelajaran Arias Ber-Setting Model Kooperatif Tipe Jigsaw. Jurnal Inovasi Pendidikan Sains. 7(1), 83,94

[3] Arfiyah, A., Mulyani, S., \& Saputro, S., 2016. Pengaruh Pembelajaran Problem Based Learning (PBL) Dilengkapi Dengan Kompendium Al-Qur'an Terhadap Minat Dan Prestasi Belajar Siswa (Pokok Bahasan Konsep Mol Kelas X Matematika dan Ilmu Alam (MIA) MAN 2 Madiun Semester Genap Tahun Pelajaran 2014/2015). Jurnal Pendidikan Kimia (JPK), 5 (1), 96-104

[4] Jauhariningsih. R., 2017. Upaya Meningkatkan Hasil Belajar Kimia Materi Asam dan Basa Dengan Menggunakan Inquiry Based Learning (IBL) Pada Kelas XI IPA 2 SMA Negeri 5 Makassar. Jurnal Nalar Pendidikan, 5(2)

[5] Murjani, A. \& Hamid, A., 2016. Meningkatkan Kemampuan Berpikir Kreatif Dan Hasil Belajar Siswa Melalui Model Pembelajaran Generatif Pada Materi Larutan Penyangga. Jurnal Inovasi Pendidikan Sains, 7 (2), 103-108

[6] Naibaho, L. (2019). Teachers'roles On English Language Teaching: A Students Centered Learning Approach. International Journal of ResearchGranthaalayah, 7(4), 206-212.

[7] Nurhasanah, S. \& Sobandi, A., 2016. Minat Belajar Sebagai Determinan Hasil Belajar Siswa. Jurnal Pendidikan Manajemen Perkantoran, 1 (1), 128-135

[8] Purba, L.S.L., 2017. Pengaruh Penerapan Model Pembelajaran Kooperatif tipe Two Stay-Two Stray (TS-TS) Terhadap Hasil Belajar dan Aktivitas Belajar Siswa Pada Pokok Bahasan Koloid. Jurnal Pendidikan, Matematika dan Sains, 1(2), 137-152

[9] Simatupang, N. I., 2016. Penggunaan Media Power Point Pada Model Pembelajaran Kooperatif Tipe Numbered Head Together (NHT) Untuk Meningkatkan Hasil Belajar Kimia Siswa. Jurnal EduMatSains, 1(1), 61-72
[10] Sitompul, D.N., 2018. Penerapan Model Pembelajaran Scramble Untuk Meningkatkan Hasil Belajar Akuntansi. Jurnal Pendidikan Akuntansi. 1 (1), 78-94)

[11] Subagia, I. W., 2014. Paradigma Baru Pembelajaran Kimia SMA. In Prosiding Seminar Nasional MIPA.

[12] Sugiyono, 2017. Metodologi penelitian kuantitatif kualitatif dan R\&D. Alpabeta, Bandung

[13] Tyas, E. H., Sunarto, S., \& Naibaho, L. (2018). Evaluation of Students Centered Learning Learning Implementation By PPL FKIP-UKI Students At Pskd Mitra School. Jurnal Selaras: Kajian Bimbingan dan Konseling serta Psikologi Pendidikan, 1(1), 69-80.

[14] Zaenab., 2018. Model Pembelajaran Scramble. Kalimantan Barat: Pustaka One 